University of Nebraska - Lincoln

DigitalCommons@University of Nebraska - Lincoln

Faculty Papers and Publications in Animal

Science

Animal Science Department

2007

\title{
Selection and Dietary Quality of Beef Cattle Grazing Smooth Bromegrass, Switchgrass, and Big Bluestem
}

B. H. Kirch

USDA-ARS, University of Kentucky, Lexington

L. E. Moser

University of Nebraska-Lincoln, Imoser1@unl.edu

S. S. Waller

University of Nebraska-Lincoln, swaller1@unl.edu

T. J. Klopfenstein

University of Nebraska-Lincoln, tklopfenstein1@unl.edu

G. E. Aiken

USDA-ARS, University of Kentucky, Lexington

See next page for additional authors

Follow this and additional works at: https://digitalcommons.unl.edu/animalscifacpub

Part of the Animal Sciences Commons

Kirch, B. H.; Moser, L. E.; Waller, S. S.; Klopfenstein, T. J.; Aiken, G. E.; and Strickland, J. R., "Selection and Dietary Quality of Beef Cattle Grazing Smooth Bromegrass, Switchgrass, and Big Bluestem" (2007). Faculty Papers and Publications in Animal Science. 766.

https://digitalcommons.unl.edu/animalscifacpub/766

This Article is brought to you for free and open access by the Animal Science Department at DigitalCommons@University of Nebraska - Lincoln. It has been accepted for inclusion in Faculty Papers and Publications in Animal Science by an authorized administrator of DigitalCommons@University of Nebraska Lincoln. 


\section{Authors}

B. H. Kirch, L. E. Moser, S. S. Waller, T. J. Klopfenstein, G. E. Aiken, and J. R. Strickland 


\title{
Ser \\ Selection and Dietary Quality of Beef Cattle Grazing Smooth Bromegrass, Switchgrass, and Big Bluestem 1
}

\author{
B. H. Kirch, ${ }^{2}$ L. E. Moser,$\dagger$ S. S. Waller, $\uparrow$ T. J. Klopfenstein, $\neq$ G. E. Aiken, ${ }^{*}$ PAS, \\ and J. R. Strickland* \\ *Forage Animal Production Research Unit, USDA-ARS, University of Kentucky, Lexington 40546; \\ $\dagger$ Department of Agronomy and Horticulture, and $\ddagger$ Department of Animal Science, University of \\ Nebraska, Lincoln 68583
}

\begin{abstract}
The ability of grazing animals to enhance quality of diet by selection is important in production. The study determined the effects of selection on dietary quality of cattle grazing monocultures of smooth bromegrass (Bromus inermis Leyss; SB), switchgrass (Panicum virgatum L.; SG), and big bluestem (Andropogon gerardii Vitman; BB) as influenced by plant maturity. Three ruminally-fistulated steers (295 kg) strip-grazed $S B, S G$, and $B B$ at vegetative, elongation, early reproductive, and a regrowth stage of development. Selection was maximized by providing cattle access to $40 \mathrm{~kg}$ of DM/d per head. Clipped samples were compared with dietary samples accumulated during 45 min grazing following total rumen evacuation. Dietary $C P$ was enhanced 3 to $4 \%$ for $S G$ and $B B$, and $8 \%$ for $S B(P$ $<0.05)$. Dietary IVDMD was enhanced
\end{abstract}

\footnotetext{
${ }^{1} \mathrm{~A}$ contribution of the University of Nebraska Agricultural Research Division supported in part by funds provided through the Hatch Act.

${ }^{2}$ Corresponding author: brett_kirch@ars. usda.gov
}

at elongation and reproductive stages for $S G$ and $B B$ and vegetative and reproductive stages for SB. Dietary NDF was 7 to $13 \%$ less $(P<0.05)$.- in $S G$ compared with forage-on-offer, whereas there was no effect with $S B$ and $B B$ diets. Diets of cattle grazing $S G$ and $B B$ had less $A D F$ than clipped forage at elongation and reproductive stages, whereas ADF for the $S B$ diet was less at the elongation phase $(P<0.05)$. Dietary lignin did not exceed $4 \%$ whereas the grass-on-offer was much greater. Regrowth produced forage and diets comparable to the elongation stage. If adequate forage is available, the selection ability of cattle can provide a superior diet compared with forage-on-offer. When the quality of warm-season grasses has declined, animal selection allows for potentially greater animal gain when grass quality is not optimum.

Key words: smooth bromegrass, switchgrass, big bluestem, diet selection, plant maturity

\section{INTRODUCTION}

Comparisons of cattle grazing cooland warm-season grasses have shown differences in animal performance (Rowe, 1974). Animal performance on warm-season grass pastures is often better than predicted from IVDMD, CP, or fiber fractions (Forwood, 1986). Grazing animals select diets greater in $\mathrm{CP}$ and lower in fiber compared with forage-on-offer (Galt et al., 1969; Heinemann and Russell, 1969) in mixed pastures and rangeland. Grazing animals on mixed pastures or rangeland are allowed to select from different forage species to augment the diet throughout the grazing season. Thus the diversity of plant species will allow for greater selection. But when cattle are grazing on improved monoculture pastures, the ability to improve the diet is related to selection of enhanced quality plant parts within the canopy, such as leaves compared with stems (Perry and Baltensperger, 1979; Griffin and Jung, 1983). Variability found within the plant canopy structure (Anderson, 1985; Fisher et al., 1991) provides the potential to influence the selection ability of the animal to enhance quality of the diet. The cow's ability to enhance the dietary quality through selection is of greatest value when the forage quality decreases with advancing forage maturity. The objective of this study was to deter- 
mine the effects of selection by cattle grazing monocultures of smooth bromegrass (Bromus inermis Leyss.), switchgrass (Panicum virgatum L.), and big bluestem (Andropogon gerardii Vitman) on quality of diet as influenced by plant maturity.

\section{MATERIALS AND METHODS}

Established monoculture pastures of one cool-season grass, smooth bromegrass (SB), and 2 warm-season grasses, switchgrass (SG) and big bluestem (BB), were grazed from May to August in the summers of 1992 and 1993 to compare selection ability of grazing cattle. This study was conducted at the University of Nebraska Agricultural Research and Development Center near Mead, NE, using pastures located on a Sharpsburg silty clay loam soil (fine, montmorillonitic, mesic Typic Argiudoll). In 1992 and 1993, SB was fertilized in late April with $90 \mathrm{~kg} / \mathrm{ha}$ of N, whereas SG and $\mathrm{BB}$ were not fertilized but were burned in late April to simulate common production practices of the area. Each grass at vegetative, elongation, and early reproductive stages of development was grazed by the same 3 ruminally fistulated steers $(295 \pm 5 \mathrm{~kg})$. An additional sampling of regrowth of each grass was taken. All animals in this study were treated in compliance with the animal use standards of the Animal Use Committee at the University of Nebraska-Lincoln. Following the first grazing at the elongation stage, the paddock was grazed with additional cattle to a uniform level of approximately $15 \mathrm{~cm}$ in height in a 2- to 3-d period and was allowed to regrow for 4 to 8 wk to a height of approximately $45 \mathrm{~cm}$ before being sampled again (Table 1). The regrowth grazing was taken from this paddock for each grass species. Fistulated cattle strip-grazed each grass at each stage of development for a 6-d acclimation period, and diets were collected on d 7. Animals were moved daily and were allotted to areas with sufficient forage to maximize selection ability. The cattle were provided
Table 1. Collection dates for 1992 and 1993

\begin{tabular}{|c|c|c|c|c|c|c|}
\hline \multirow[b]{2}{*}{ Item } & \multicolumn{2}{|c|}{ Smooth bromegrass } & \multicolumn{2}{|c|}{ Switchgrass } & \multicolumn{2}{|c|}{ Big bluestem } \\
\hline & 1992 & 1993 & 1992 & 1993 & 1992 & 1993 \\
\hline \multicolumn{7}{|c|}{ Stage $^{1}$} \\
\hline VG & May 12 & May 12 & June 16 & June 9 & June 23 & June 16 \\
\hline EL & May 19 & May 19 & June 30 & June 23 & July 22 & July 7 \\
\hline $\mathrm{RP}$ & May 29 & May 26 & July 29 & July 28 & August 4 & August 4 \\
\hline RG & July 21 & July 21 & August 18 & August 11 & August 24 & August 18 \\
\hline
\end{tabular}

${ }^{1} \mathrm{VG}$ = vegetative; $\mathrm{EL}=$ elongation; $\mathrm{RP}$ = reproductive; $\mathrm{RG}=$ regrowth . at least $40 \mathrm{~kg}$ of $\mathrm{DM} / \mathrm{d}$ per head of forage (Table 2), which is in excess of the maximum levels of consumption (12 to $18 \mathrm{~kg}$ of DM/d per head) as defined by Mott (1981). The distribution of forage production of each grass was estimated using procedures described in Waller et al. (1986).

On d 7 of the grazing period, diet selection samples were obtained following total rumen evacuation. After the rumen contents were emptied by hand, the animals were allowed to graze for 45 min prior to sampling the rumen for a representative sample of the selected diet. Following diet collection, rumen contents were returned and the animals were moved to the next grazing treatment or to a holding pasture depending on the maturity of the next grass to be grazed. The 1992 and 1993 collection schedules are shown in Table 1.

In conjunction with the dietary samples, clipped samples were taken to estimate quality and yield of forage mass. Prior to grazing, vegetation in 5 randomly placed $0.2-\mathrm{m}^{2}$ quadrats were clipped at the soil surface. Two of the samples were selected to determine the stage of maturity. Stage of developmental morphology was esti-
Table 2. Mean stage count (MSC), yield, herbage allowance, and leafto-stem ratio of smooth bromegrass (SB), switchgrass (SG), and big bluestem (BB) forage by stage

\begin{tabular}{lcccccc} 
Item & Stage $^{1}$ & MSC & SE $^{2}$ & $\begin{array}{c}\text { Yield } \\
(\mathbf{m g} / \mathbf{h a})\end{array}$ & $\begin{array}{c}\text { Herbage } \\
\text { allowance } \\
\text { (kg/d per head) }\end{array}$ & $\begin{array}{c}\text { Leaf-to-stem } \\
\text { ratio }\end{array}$ \\
\hline $\begin{array}{l}\text { Species } \\
\text { SB }\end{array}$ & VG & 1.62 & 0.31 & 2.8 & 56 & \\
& EL & 2.02 & 0.44 & 3.7 & 62 & 1.1 \\
& RP & 2.51 & 0.49 & 4.3 & 43 & 1.3 \\
& RG & 2.02 & 0.43 & 2.4 & 48 & 2.9 \\
SG & VG & 1.74 & 0.38 & 2.5 & 104 & 1.7 \\
& EL & 2.06 & 0.37 & 3.4 & 40 & 1.0 \\
& RP & 2.65 & 0.49 & 6.3 & 53 & 0.5 \\
BB & RG & 2.17 & 0.54 & 3.4 & 68 & 0.7 \\
& VG & 1.38 & 0.15 & 3.5 & 175 & 2.4 \\
& EL & 1.51 & 0.26 & 5.4 & 72 & 2.3 \\
& RP & 2.01 & 0.72 & 8.4 & 84 & 1.2 \\
& RG & 1.54 & 0.32 & 3.5 & 70 & 1.3
\end{tabular}

${ }^{1} \mathrm{VG}$ = vegetative; $\mathrm{EL}=$ elongation; $\mathrm{RP}$ = reproductive; $\mathrm{RG}=$ regrowth .

${ }^{2} \mathrm{SE}=$ the variation of the tiller population which constitutes the MSC. 
mated by mean stage count (MSC) developed by Moore et al. (1991). Each sample was also separated by leaf blade and stem and sheath to develop a leaf-to-stem ratio.

\section{Sample Processing and Analysis}

Following collection, the dietary samples were immediately placed on ice and transferred to laboratories in Lincoln, NE. Dietary samples were stored at $-20^{\circ} \mathrm{C}$ until they were prepared for analysis. Dietary samples were lyophilized and ground with a Wiley mill (Arthur Thomas Co., Philadelphia, PA) to pass through a 1-mm screen. Due to limited freeze-drying capacity, clipped samples of each of the grass species at each stage of maturity were dried in forced-air ovens at $55^{\circ} \mathrm{C}$, and the sample was recombined with the MSC subsamples and ground to pass through a 1-mm screen. All samples were analyzed for CP by macro Kjeldahl (AOAC, 1990) and IVDMD (Marten and Barnes, 1980). The IVDMD was determined using the method of Tilley and Terry (1963) modified with the addition of $0.8 \mathrm{~g} / \mathrm{L}$ of urea to the McDougall's buffer (Weiss, 1994). Rumen fluid collected for the IVDMD was collected from cattle being fed grass hay and alfalfa diets. Samples also were analyzed for NDF, ADF, ADL, and ash (Goering and Van Soest, 1970). The NDF and ADF techniques were performed independently and without using $\mathrm{Na}_{2} \mathrm{SO}_{4}$ and acetone.

\section{Clipped Forage Adjustment}

The results of the clipped forage samples were adjusted to a freezedried basis for comparison with the dietary samples. An independent study was performed to develop adjustments at each stage of maturity of each grass species for the purposes of comparing forage samples with the lyophilized masticate samples. Four replicated plots of SB, SG, and BB were harvested at the vegetative, elongation, and early reproductive stages of plant development. A $0.1 \mathrm{~m}^{2}$ quadrat was clipped from each replicate. Each clipped sample was staged by maturity, recombined, and randomly divided into 2 subsamples. One sample was lyophilized and the other subsample was oven-dried at $55^{\circ} \mathrm{C}$. Each sample was analyzed for CP, IVDMD, NDF, ADF, ADL, and ash. The resulting differences were statistically analyzed and used to develop a single numerical correction for each species at each maturity, was applied to the nutritional component of the ovendried samples in the grazing study for comparison purposes (Kirch, 1995). Adjustments to clipped samples for CP were increased by 2.4 in the vegetative stage for SB and were decreased by an average of 1.7 units across the other maturities for the oven-dried samples. For the oven-dried CP, SG and $\mathrm{BB}$ clip samples were decreased by an average of 0.3 and 0.2 units, respectively, across all maturities. The IVDMD of clipped samples was reduced by 1.6 for SB at each maturity, and were increased by 1.5 and 2.9 units for SG and BB samples, respectively, at each maturity. The values of the oven-dried NDF analysis were decreased by $5.7,0.8$, and 2.7 units for SB, SG, and BB, respectively, at each maturity. The ADF of clip samples was decreased by 1.8 units for each maturity for $\mathrm{SB}, \mathrm{SG}$, and $\mathrm{BB}$. The values for ADL were similar to ADF in that each sample was reduced by 0.04 units at each maturity of each grass species.

\section{Statistical Analysis}

This study utilized techniques described in Vogel et al. (1991) for analyzing the data to compare esophageal and hand-clipped samples. Comparisons between dietary samples in this study were analyzed using a crossover design. Comparisons among clipped samples were analyzed using a split-plot design with grass species as the treatment (main plot) and stage of plant development as the subplot. Individual species and maturity treatment combinations utilized paired $t$-tests to determine significant quality differences between animal diet and clipped forage samples. Be-
Table 3. Main effects for grass species and plant development effects on CP, NDF, and ash composition of forage-on-offer of smooth bromegrass (SB), switchgrass (SG), and big bluestem (BB) at different stages of plant development

\begin{tabular}{|c|c|c|c|}
\hline Item & $\mathrm{CP}^{1}$ & $\mathrm{NDF}^{1}$ & $\mathrm{ASH}^{\top}$ \\
\hline & & $\%$ DM & \\
\hline \multicolumn{4}{|l|}{ Stage $^{2}$} \\
\hline VG & 14.0 & 63.6 & 3.1 \\
\hline EL & 9.2 & 68.1 & 3.2 \\
\hline $\mathrm{RP}$ & 6.2 & 70.3 & 2.8 \\
\hline RG & 9.6 & 69.2 & 4.7 \\
\hline $\mathrm{LSD}_{0.05}$ & 0.8 & NS & 0.5 \\
\hline \multicolumn{4}{|l|}{ Species } \\
\hline SB & 14.6 & 57.6 & 2.9 \\
\hline SG & 7.5 & 73.7 & 3.2 \\
\hline BB & 7.2 & 72.2 & 4.3 \\
\hline $\mathrm{LSD}_{0.05}$ & 0.7 & 0.9 & 0.4 \\
\hline
\end{tabular}

${ }^{1}$ Species $\times$ stage interaction $(P>$ 0.10 ).

${ }^{2} \mathrm{VG}$ = vegetative; $\mathrm{EL}=$ elongation;

$\mathrm{RP}=$ reproductive; $\mathrm{RG}=$ regrowth .

cause of constraints of pastures and animals, years were used as replication. The pastures were managed identically each year including the randomization of the paddocks within pastures to eliminate potential carry-over year effects. The statistical analysis of this study was accomplished using the GLM procedure of SAS (1985). Means for clipped and dietary samples were separated using Fisher's protected least significant difference at $\alpha=0.05$ (Steele and Torrie, 1980).

\section{RESULTS AND DISCUSSION}

Averaged over the 3 species, CP of forage-on-offer was highest at the vegetative stage of maturity (Table 3 ) and declined $56 \%$ from vegetative to early reproductive stage. Similar declines in CP were observed in SB, SG, and BB by Mitchell et al. (1997) and Newell and Moline (1978). Diet sample $\mathrm{CP}$ declined from vegetative to 
Table 4. Grass species and plant development effects on CP, IVDMD, NDF, ADF, and ADL composition of diets of cattle grazing smooth bromegrass (SB), switchgrass (SG), and big bluestem (BB) at different stages of plant development

Item

CP

IVDMD

NDF

ADF

ADL

\section{Stage}

VG

EL

RP

RG

$\mathrm{LSD}_{0.05}$

Species

SB

SG

BB

$\mathrm{LSD}_{0.05}$

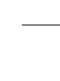

16.5

15.5

12.2

15.0

1.5

20.7

11.8

11.9

1.3

77.4
71.7
70.5
69.7
2.6
75.6
72.0
69.4
2.3

59.2

60.2

63.4

59.6

2.1

52.0

62.1

67.7

1.8

34.5
35.9
37.7
36.2
1.4

32.9
36.4
39.0
1.2

1.2

influenced by a tiller population that was more diverse or contained more vegetative tillers in the regrowth population than at early reproductive stage.

For IVDMD the analysis of the data provided a significant species $\times$ maturity interaction $(P<0.05)$ for the forage-on-offer. The IVDMD of forageon-offer (Figure 2) in SG and BB declined 36 and $26 \%$, respectively $(P<$ $0.05)$, from vegetative to early reproductive stage, whereas that for SB did not decline during the same stages of development $(P>0.10)$. The decrease of IVDMD from vegetative to early reproduction is characteristic of the quality changes observed in warm-season grasses (Newell and Moline, 1978; Griffin and Jung, 1983; Mitchell et al., 1994). However, the lack of a decrease in IVDMD in the forageon-offer of SB and the overall high IVDMD of all 3 species at the vegetative stage was unusual and may be attributed to the weather. The SB grazing treatments occurred in May under cool temperatures, and adequate precipitation for the entire grazing season favored vegetative or high quality growth in SB and in the initial growth of $\mathrm{SG}$ and $\mathrm{BB}$. The IVDMD of diets averaged across all 3 grasses declined by $9 \%$ from vegetative to early reproductive stages $(P<$ 0.05; Table 4). Improvement of the diet selected over forage-on-offer was similar for SG and BB (Figure 2).

With warm-season grasses at the vegetative stage, animals were unable to significantly $(P>0.10)$ improve the IVDMD in their diets over the forageon-offer. At elongation, diets of warm-season grasses were $8 \%$ greater in IVDMD than the forage-on-offer, and at early reproduction, diets were greater than forage-on-offer by $42 \%$ for SG and 19\% for BB. Diets of SB were about $10 \%$ greater in IVDMD at vegetative and early reproductive stages than the forage-on-offer. Due to the high IVDMD of the SB forageon-offer (Table 4), improvements in diet IVDMD were not likely of major biological significance because forage intake was probably controlled by 


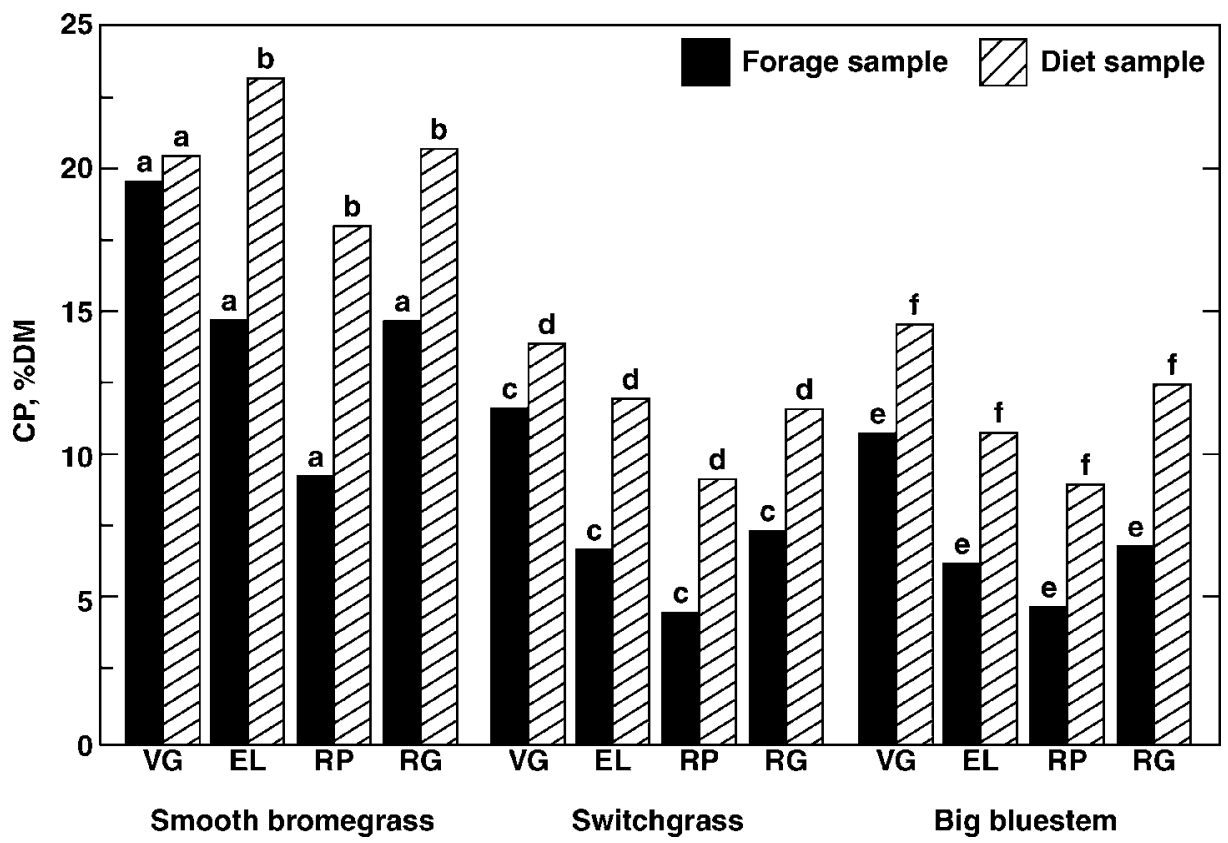

Figure 1. Crude protein in forage-on-offer and selected diet of cattle grazing smooth bromegrass, switchgrass, and big bluestem at vegetative $(V G)$, elongation $(E L)$, early reproductive $(R P)$, and regrowth $(R G)$ stages of plant development. Bar pairs within grass species comparing

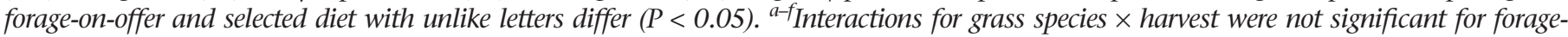
on-offer and selected diet $(P>0.10)$.

chemostatic factors due to the high quality of the forage. With SB,

IVDMD never dropped below 67.7\%, which may be the upper limit at which intake is no longer controlled by fill but is controlled instead by chemostatic factors (Conrad, 1966). In this study on only 2 occasions did average IVDMD of diets selected de-

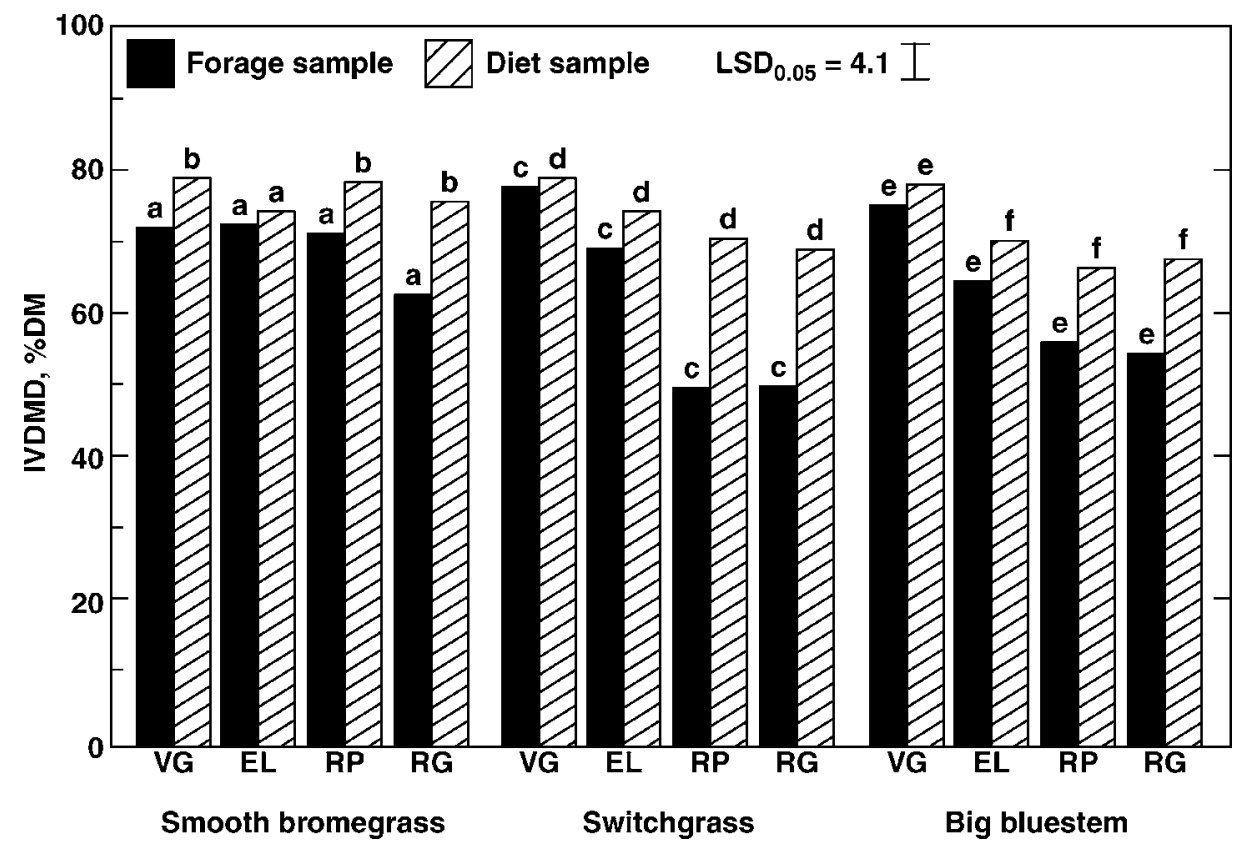

Figure 2. In vitro dry matter disappearance in forage-on-offer and selected diet of cattle grazing smooth bromegrass, switchgrass, and big bluestem at vegetative $(V G)$, elongation (EL), early reproductive $(R P)$, and regrowth $(R G)$ stages of plant development. Forage-on-offer sample mean separation for species $\times$ harvest interaction $\left(L S D_{0.05}=4.1\right)$. ] Bar pairs within grass species comparing forage-on-offer and selected diet with unlike letters differ $(P<0.05)$. ${ }^{a-f}$ Interactions for grass species $\times$ harvest were not significant for selected diet $(P>0.10)$. 
crease below $70 \%$, which was during the early reproductive and regrowth stages of BB.

The IVDMD of the forage-on-offer at regrowth was similar to the early reproductive stage in $\mathrm{SG}$ or $\mathrm{BB}$, whereas in SB the IVDMD of regrowth was less $(P<0.05)$ than the 3 previous stages of plant development (Figure 2). Dietary IVDMD for regrowth of all 3 species was similar to the elongation stage (Table 4).

The decline in whole-plant IVDMD of SB regrowth, the relatively low IVDMD of SG and BB regrowth, and increases in fiber may be attributed to the environment in which the regrowth developed. The regrowth of all 3 grasses developed during periods when temperatures were higher than during the early stages of grass development. Decreased IVDMD and greater fiber in cool- and warm-season grasses grown under higher temperatures was demonstrated by Ford et al. (1979).

The NDF of forage-on-offer (Table 3 ) tended to increase for all 3 grasses from vegetative to early reproduction, but was not significant $(P>0.10)$. Switchgrass had the highest NDF throughout the grazing season $(P<$ $0.05)$. Increased NDF with maturity is characteristic of fiber accumulation in warm-season grasses (Griffin and Jung, 1983), primarily due to decreased leaf-to-stem ratio (Table 2). Species $\times$ maturity interactions were not significant for dietary or forageon-offer NDF $(P>0.10)$

Diets of animals grazing BB and SG were greater in NDF composition $(P<$ $0.05)$ than those of SB. The NDF concentration in the masticate sample for warm-season grasses was parallel to trends of the forage-on-offer. The ability to select a diet with less NDF was most prevalent in SG (Figure 3). Cattle grazing SG were able to select a diet with less NDF from the forageon-offer at each of the 3 maturities ( $P$ $<0.05)$. Cattle grazing BB reduced their diet NDF $(P<0.05)$ at elongation and early reproductive growth stages; whereas the diet NDF of SB was less than the forage-on-offer only at the elongation stage. The ability of cattle grazing SG to select a diet dramatically reduced in NDF when compared with SB and BB may be a function of the canopy structure.

Switchgrass has an upright canopy structure that elevates enhanced quality leaves to the top of the canopy (Anderson, 1985; Fisher et al., 1991), which leads to a stratified or layered grazing of SG (Anderson, 1985). With the light stocking rates in the current study, the cattle were not forced to graze deep into the canopy, whereas grazing in SB and BB was spot-directed with the animals grazing deeper into the canopy on a specific selected plant.

The NDF of forage-on-offer in regrowth of all 3 grass species was not different $(P<0.05$ : Table 3$)$ from any of the 3 previous maturities. The NDF in the diets of regrowth were similar to vegetative and elongation stages $(P$ $<0.05$; Table 4). Animals grazing SB regrowth were able to select a diet with less NDF than the forage-on-offer $(P<0.05$; Figure 3$)$. The magnitude of diet improvement was greatest for SB and SG with a 16\% decrease in NDF, whereas BB diet decreased by $7 \%$ in NDF compared with the forage-on-offer $(P<0.05)$.

The species $\times$ maturity interaction was significant $(P<0.05)$ for the ADF of the forage-on-offer. The ADF for SG and BB increased $(P<0.05)$ at each grazing from vegetative to early reproductive stages (Figure 4), whereas ADF of SB remained relatively constant across the same plant developmental stages. Due to effects of grass development and leaf-to-stem ratios, diets increased in $\mathrm{ADF}(P<$ 0.05 ) from vegetative to early reproductive stages (Table 4). The ADF was lowest in the SB diet whereas the diet of BB had the highest. The ability of cattle to select a diet with less ADF than the forage-on-offer was significant in SG and BB in the elongation and early reproductive stages $(P<$ 0.05; Figure 4). This was similar to the trend observed in IVDMD, where animals were unable to augment diets at the early developmental stage of the grass. When grazing SB, animals selected a diet with less ADF at the elongation stage. This is contrary to observed trends in IVDMD of SB diets. Similar trends observed for IVDMD and ADF seem to be more prevalent in SG and BB than in SB, which would be supported by findings of Reid et al. (1988), who determined DM digestibilities are more highly correlated with ADF in warmseason grass than in cool-season grass.

The ADF of forage-on-offer in SB regrowth was greater than all previous stages. The $\mathrm{ADF}$ of $\mathrm{BB}$ regrowth forage was similar to elongation and early reproductive stages, whereas SG regrowth forage was lower $(P<0.05)$ in ADF than the early reproductive stage, but greater than vegetative and elongation forage-on-offer. The ADF in regrowth masticate samples was similar to elongation stage diets across all 3 grass species (Table 4). Animals grazing regrowth were able to select a diet 15 to $16 \%$ lower in ADF than in the forage-on-offer for each grass species $(P<0.05)$.

The ADL of the forage-on-offer of SB (Figure 5) increased from the vegetative to the elongation stage $(P<$ $0.05)$, but remained constant from the elongation to the early reproductive stage. Forage-on-offer of warmseason grass increased in ADL composition with advancing maturity; SG increased by over 2-fold from the vegetative to the early reproductive stage $(P<0.05)$, whereas BB increased in ADL composition slowly from vegetative to elongation $(P>0.05)$ and then dramatically increased from elongation to early reproductive stages $(P<$ 0.05 ), producing a 1.5 -fold increase over the vegetative stage. Increases in ADL concentration are expected with the increases in the growing temperature (Ford et al., 1979; Henderson and Robinson, 1982). Dramatic increases of $\mathrm{ADL}$ in SG and $\mathrm{BB}$ are the result of lignification associated with cell wall maturation and the increase in stem proportion of the plant. In diet samples, ADL remained nearly constant across maturities for each 


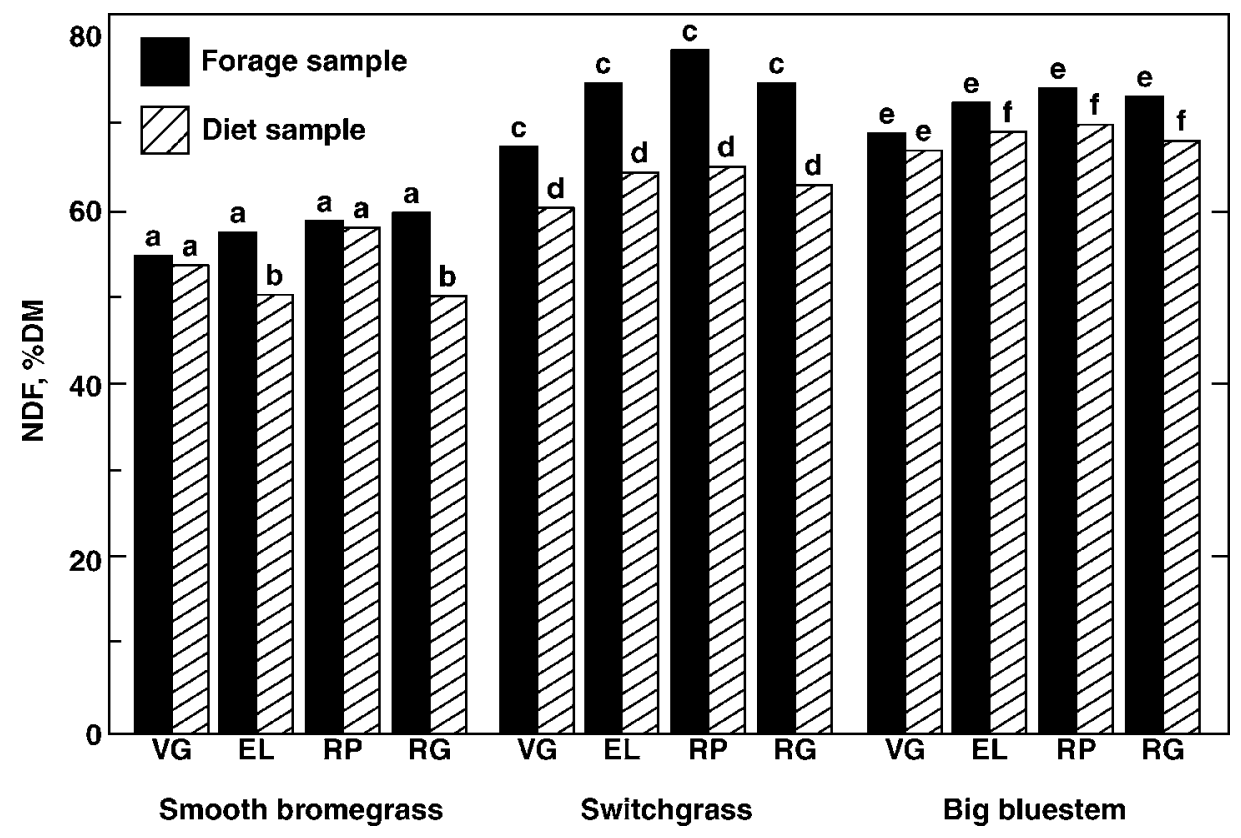

Figure 3. Neutral detergent fiber in forage-on-offer and selected diet of cattle grazing smooth bromegrass, switchgrass, and big bluestem at vegetative $(V G)$, elongation (EL), early reproductive $(R P)$, and regrowth $(R G)$ stages of plant development. Bar pairs within grass species comparing forage-on-offer and selected diet with unlike letters differ $(P<0.05) .{ }^{a-f}$ Interactions for grass species $\times$ harvest were not significant for forage-on-offer and selected diet $(P>0.10)$.

grass species (Table 4). The SB diet averaged 3.1\% ADL across all maturities, whereas SG and BB diets aver- aged 3.6 and 3.9\%, respectively, during the same maturities. The ability of the animals to reduce diet ADL in comparison to forage-on-offer was evident $(P<0.05)$ at elongation and early reproductive stages of all 3

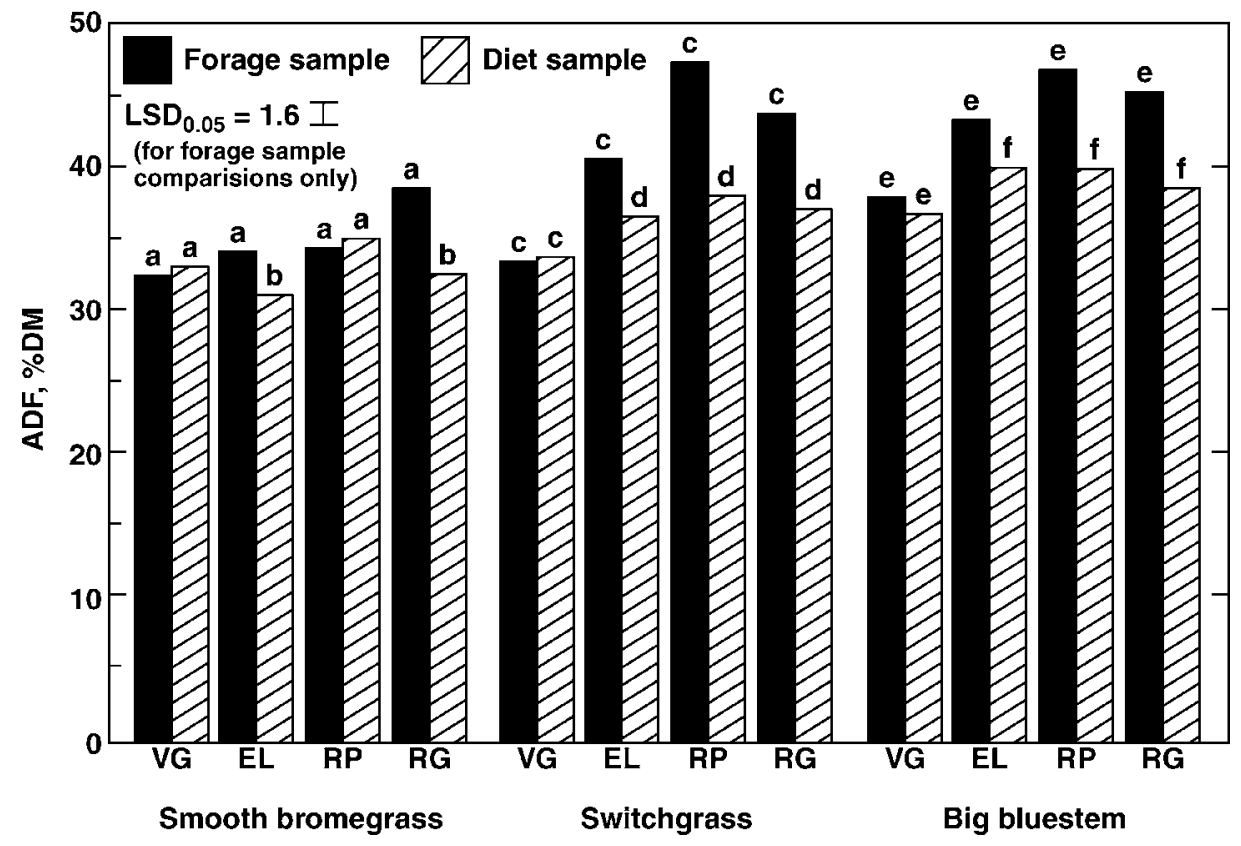

Figure 4. Acid detergent fiber in forage-on-offer and selected diet of cattle grazing smooth bromegrass, switchgrass, big bluestem at vegetative $(V G)$, elongation $(E L)$, early reproductive $(R P)$, and regrowth $(R G)$ stages of plant development. Forage-on-offer sample mean separation for species $\times$ harvest interaction $\left(L S D_{0.05}=1.6\right)$. Bar pairs within grass species comparing forage-on-offer and selected diet with unlike letters differ $(P<0.05)$. ${ }^{a-f}$ Interactions for grass species $\times$ harvest were not significant for selected diet $(P>0.10)$. 


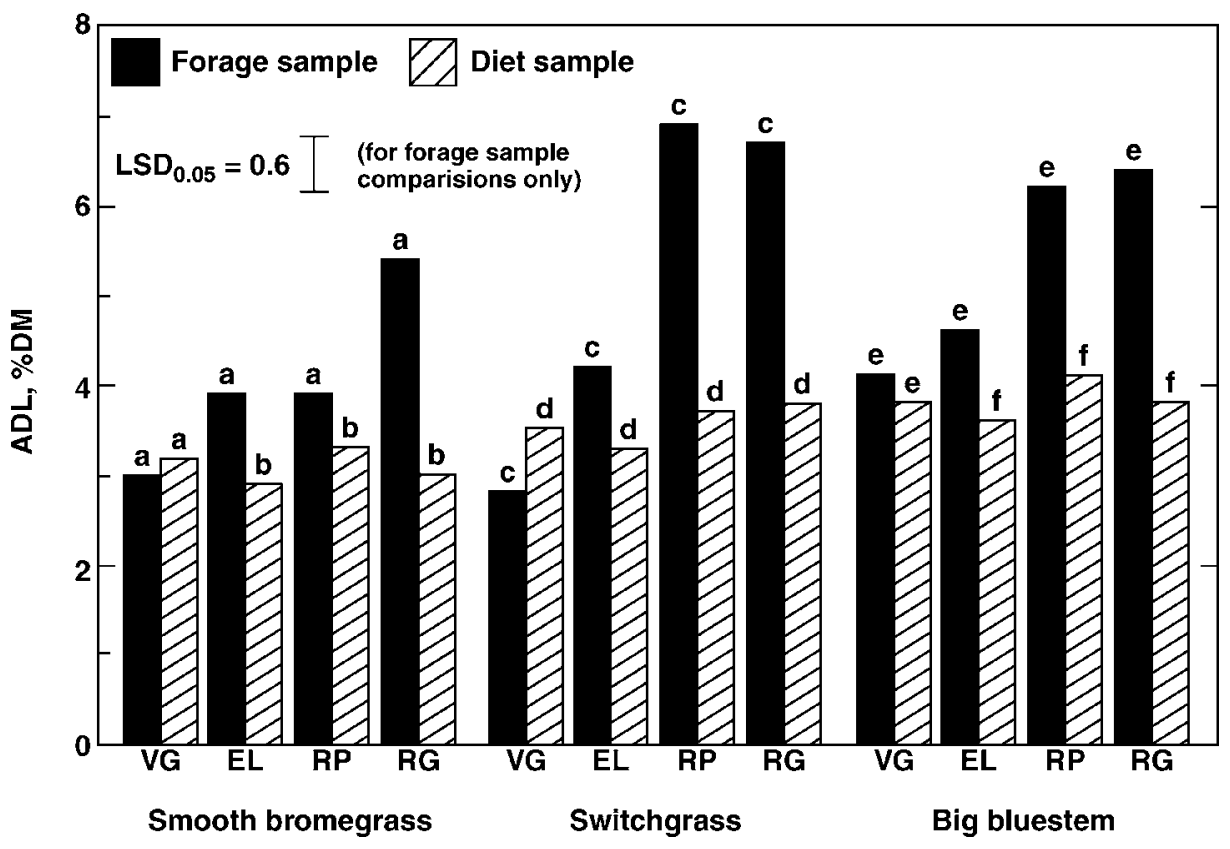

Figure 5. Acid detergent lignin in forage-on-offer and selected diet of cattle grazing smooth bromegrass, switchgrass, and big bluestem at vegetative $(V G)$, elongation (EL), early reproductive (RP), and regrowth (RG) stages of plant development. Forage-on-offer sample mean separation for species $\times$ harvest interaction $\left(L S D_{0.05}=0.6\right)$. Bar pairs within grass species comparing forage-on-offer and selected diet with unlike letters differ $(P<0.05)$. ${ }^{a-f}$ Interactions for grass species $\times$ harvest were not significant for selected diet $(P>0.10)$.

grasses, but not at the vegetative stage (Figure 5). Regardless of the grass species, diet concentrations of ADL maximized at about $4.0 \%$ even though forage-on-offer in SG and BB was considerably greater (Table 4)

Forage-on-offer of SB regrowth was substantially greater in ADL than in the 3 previous maturities $(P<0.05$; Figure 5). The ADL in warm-season grass regrowth also was high, but comparable to early reproduction. The ADL in regrowth-selected diets was similar to each of the previous maturities in each of the grass species (Table 4).

Ash concentrations of diet samples may differ from forage-on-offer due to potential contamination of diet by saliva and soil contamination. In this study, the differences between the forage-on-offer and diet samples were small. Ash values averaged 3.6\% for forage-on-offer and $4.1 \%$ for diet samples. Differences $(P<0.05)$ in ash were noted in the forage-on-offer with effects due to species and maturity (Table 3). Big bluestem forage-onoffer averaged across all stages of plant development was $4.3 \%$ ash compared with 3.2 and $2.9 \%$ of SG and $\mathrm{SB}$, respectively. Diet samples of all 3 species did not vary for any maturity nor was there any difference in the diet of any grass averaged across all maturities. Diets compared with forage-on-offer were different in 6 out of 12 maturities. In 3 maturities dietary ash was greater than the forageon-offer, whereas in the other 3 maturities, forage-on-offer was greater than the diet, with no trends for species of grass or stage of plant development.

Utilizing warm-season grasses for ruminant production is limited at times because of low quality of the forage, especially late in the growing season. The ability of the grazing animals to augment their diets in relation to $\mathrm{CP}$ and IVDMD when grazing warm-season grass monocultures can be used as a management strategy for the producer to maintain growing animal performance late in the grazing season. A potential scheme would involve grazing cool-season grasses early in the season when quality and growth is high and warm-season grass with heavy stocking rates early in the summer when forage quality is high, followed by reduced stocking rates later in the season when the opportunity to selectively graze could be maximized. Regrowth from cool- and warm-season grasses could be utilized to help bridge the gap of the late summer deficits. Animal performance throughout the season could be greater when compared with traditional constant stocking rates. However, such grazing systems must be managed to not decrease grass persistence or vigor. This would allow utilization of warm-season grass during periods when high quality forage is limited and just prior to returning to fall grazing of cool-season grass.

Utilization of regrowth in each of these grasses provides a high quality forage source, especially $\mathrm{CP}$, during late summer when $\mathrm{CP}$ of mature SG and $\mathrm{BB}$ has diminished severely. Use of warm-season grass regrowth and the reduction of stocking rates to maximize selective grazing may provide options to the producer of the Great Plains region to maintain animal performance through late summer when performance on warm-sea- 
son grasses normally declines and forage resources are limited.

\section{IMPLICATIONS}

The ability of animals to selectively improve their diet when grazing monocultures of cool- and warm-season grasses could lead to grazing schemes that allow the producer to better utilize these grasses as forage quality decreases to levels below the minimum requirements of grazing animals. Quantification of dietary quality also allows for prescriptive diet supplementation to optimize animal performance. The selection ability of animals grazing warm-season grasses may help explain the improvements in performance over performance predicted from common whole-plant forage quality parameters, especially as grasses mature.

\section{LITERATURE CITED}

Anderson, B. 1985. The influence of aging on forage quality of individual switchgrass leaves and stems. Page 947 in Proc. 15th Int. Grassl. Congr. Proc. Soc. Grassl. Sci. Nishi-nasuno, Tochigiken, Japan.

AOAC. 1990. Official Methods of Analysis. 15th ed. Association of Official Analytical Chemists, Arlington, VA.

Cable, D. R., and R. P. Shumway. 1966. Crude protein in rumen contents and in forage. J. Range Manage. 19:124

Conrad, H. R. 1966. Symposium on factors influencing the voluntary intake of herbage by ruminants: Physiological and physical factors limiting feed intake. J. Anim. Sci. 25:227.

Fisher, D. S., J. C. Burns, K. R. Pond, R. D. Mochrie, and D. H. Timothy. 1991. Effects of grass species on grazing steers: I. Diet composition and ingestive mastication. J. Anim. Sci. 69:1188.

Ford, C. W., I. M. Morrison, and J. R. Wilson. 1979. Temperature effects on lignin, hemicellulose and cellulose in tropical and temperate grasses. Aust. J. Agric. Res. 30:621.
Forwood, J. R. 1986. Warm-season grazing management'the animal response. In Warmseason grasses: Facts and fantasy. Proc. Four State Grassl. Manage. Workshop. Northwest Missouri State Univ., Maryville, MO.

Galt, H. D., B. Theurer, J. H. Ehrenreich, W. H. Hale, and S. C. Martin. 1969. Botanical composition of diet of steers grazing a desert grassland range. J. Range Manage. 22:14.

Goering, H. K., and P. J. Van Soest. 1970. Forage Fiber Analyses (Apparatus, Reagents, Procedures, and Some Applications). Agric. Handbook No. 379. ARS-USDA, Washington, DC.

Griffin, J. L., and G. A. Jung. 1983. Leaf and stem forage quality of big bluestem and switchgrass. Agron. J. 75:723.

Heinemann, W. W., and T. S. Russell. 1969. Evaluation of rotation grazed pastures from esophageal and hand gathered forage samples. Agron. J. 61:547.

Henderson, M. S., and D. L. Robinson. 1982. Environmental influences of fiber component concentrations of warm-season perennial grasses. Agron. J. 74:573.

Jolitz, E. C. 1979. The phenology of spring growth and quality of smooth bromegrass, meadow bromegrass, and orchardgrass. M.S. Thesis, Univ. of Nebraska, Lincoln.

Kirch, B. H. 1995. Rumen escape protein and diet quality of cattle grazing smooth bromegrass, switchgrass, and big bluestem. PhD Diss., University of Nebraska, Lincoln.

Marten, G. C., and R. F. Barnes. 1980. Prediction of energy digestibility of forages with in vitro rumen fermentation and fungal enzymes. Page 61 in Standardization of Analytical Methodology OF Feeds. W. J. Pigden, C. C. Balch, and M. Graham, ed. Int. Dev. Res. Ctr., Ottawa, Canada.

Mitchell, R. B., R. A. Masters, S. S. Waller, K. J Moore, and L. E. Moser. 1994. Big bluestem production and forage quality responses to burning date and fertilizer in tallgrass prairies. J. Prod. Agric. 7:355.

Mitchell, R. B., D. D. Redfearn, L. E. Moser, R. J. Grant, K. J. Moore, and B. H. Kirch. 1997. Relationships between in situ protein degradability and grass development morphology. J. Dairy Sci. 80:1143.

Moore, K. J., L. E. Moser, K. P. Vogel, S. S. Waller, B. E. Johnson, and J. F. Pedersen. 1991. Describing and quantifying growth stages of perennial forage grasses. Agron. J. 83:1073

Mott, G. O. 1981. Measuring forage quantity and quality in grazing trials. Page 3 in Proc. 37th Southern Pasture and Forage Crop Im- prov. Conf., Nashville, TN. Agric. Res. Sci. Educ. Admin., New Orleans, LA.

Mowat, D. N., R. S. Fulkerson, W. E. Tossell, and J. E. Winch. 1965. The in vitro digestibility and protein content of leaf and stem portions of forages. Can. J. Plant Sci. 45:321.

Newell, L. C., and W. J. Moline. 1978. Forage quality evaluations of twelve grasses in relation to season for grazing. Univ. Nebraska Agric. Exp. St. Res. Bull. 283.

NRC. 1984. Nutrient Requirements of Beef Cattle. 6th ed. Natl. Acad. Press, Washington, DC.

Perry, L. J., Jr., and D. D. Baltensperger. 1979. Leaf and stem yields and forage quality of three $\mathrm{N}$-fertilized warm-season grasses. Agron. J. 71:355.

Reid, R. L., G. A. Jung, and W. V. Thayne. 1988. Relationship between nutritive quality and fiber components of cool season and warm season forages: a retrospective study. J. Anim. Sci. 66:1275.

Rowe, S. W. 1974. A study of forage production, forage quality, and associated animal performance of cool- and warm-season grass pastures. M.S. Thesis, Univ. of Nebraska, Lincoln.

SAS. 1985. SAS User¥s Guide: Statistics. Version 5 ed. SAS Inst. Inc., Cary, NC.

Smart, A. J., W. H. Schacht, J. D. Volesky, and L. E. Moser. 2006. Seasonal changes in dry matter partitioning, yield, and crude protein of intermediate wheatgrass and smooth bromegrass. Agron. J. 98:986.

Steele, R. G. D., and J. H. Torrie. 1980. Principles and Procedures of Statistics: A Biometrical Approach. 2nd ed. McGraw-Hill Book Co., New York, NY.

Tilley, J. M. A., and R. A. Terry. 1963. A twostage technique for in vitro digestion of forage crops. J. Br. Grassl. Soc. 18:104

Vogel, K. P., K. J. Moore, and B. E. Johnson. 1991. Statistical analyses for comparison of esophageal and hand-clipped samples from grazing trials. J. Range Manage. 44:379.

Waller, S. S., L. E. Moser, and B. E. Anderson. 1986. A guide for planning and analyzing a year-round forage program. Univ. Nebraska Coop. Ext. Bull. EC 86-113-C.

Weiss, W. P. 1994. Estimation of digestibility of forages by laboratory methods. Page 644 in Forage Quality, Evaluation, and Utilization. G. C. Fahey, Jr., ed. Am. Soc. Agron., Crop Sci. Soc. Am., Soil Sci. Soc. Am., Madison, WI. 